\title{
Effect of Mn Substitution on the Electrochemical Properties of $\mathrm{LiTi}_{2}\left(\mathrm{PO}_{4}\right)_{3}$
}

\author{
A.VENKATESWARA RAO ${ }^{\mathrm{a}^{*}}, \mathrm{~V}$.VEERAIAH ${ }^{\mathrm{a}}$, \\ A.V.PRASADA RAO ${ }^{b}$ and B.KISHORE BABU ${ }^{c}$
}

${ }^{a}$ Department of Physics, ${ }^{b}$ Department of Inorganic and Analytical Chemistry,

${ }^{\mathrm{c}}$ Department of Engineering Chemistry, Andhra University, Visakhapatnam, 530003, India avrtoavr@gmail.com

Received 21 July 2012 / Accepted 16 August 2012

\begin{abstract}
Mn substituted $\mathrm{LiTi}_{2}\left(\mathrm{PO}_{4}\right)_{3}$ samples of composition $\mathrm{LiMn}_{\mathrm{x}} \mathrm{Ti}_{2-\mathrm{x}}\left(\mathrm{PO}_{4}\right)_{3}(\mathrm{x}=0.0,0.1,0.3$ and 0.5$)$ have been prepared by solid-state method. XRD studies indicated formation of phase pure materials of rhombohedral structure. Micro structural studies by scanning electron microscopy (SEM) revealed particle size in the range of microns. Conductivity results from $313 \mathrm{~K}$ to $573 \mathrm{~K}$ showed high ionic conductivity for low amount of $\mathrm{Mn}$ and electronic conductivity results are well correlated with ionic conductivity studies. Cyclic voltammetry results showed its electrochemical stability and reaction mechanism in the voltage range from 0.5 to $3.5 \mathrm{~V}$.
\end{abstract}

Keywords: Lithium titanium phosphate, $\mathrm{Mn}$ doped $\mathrm{LiTi}_{2}\left(\mathrm{PO}_{4}\right)_{3}$, Ionic conductivity, Electronic conductivity

\section{Introduction}

Exploitation of insertion oxides as host materials for rechargeable batteries has been the subject of many researchers to power several portable electronic devices such as cell phones, laptops, digital cameras etc. Since no other cations except $\mathrm{H}^{+}$can penetrate easily into solids than $\mathrm{Li}^{+}$, the study of rechargeable Li batteries has been actively pursued since 1970s with lithium insertion electrodes in the form of layered $\mathrm{LiCoO}_{2}$ and spinel type $\mathrm{LiMn}_{2} \mathrm{O}_{4}{ }^{1-3}$. Besides these two host materials, complex phosphates like $\mathrm{LiTi}_{2}\left(\mathrm{PO}_{4}\right)_{3}$ (LTP) with NASICON $\left[\mathrm{Na}_{3} \mathrm{Zr}_{2}\left(\mathrm{SiO}_{4}\right)_{2}\left(\mathrm{PO}_{4}\right)\right]$ structure have also been explored because of their high ionic conductivity, low thermal expansion coefficient, and low thermal conductivity ${ }^{4}$. In view of competitive energy-density storage and better thermal properties, phosphate based materials are potential candidates as cathodes for lithium ion batteries compared to traditional cathodes like $\mathrm{LiCoO}_{2}, \mathrm{LiMn}_{2} \mathrm{O}_{4}, \mathrm{~V}_{2} \mathrm{O}_{5}$, etc. LTP structure is made up of two $\mathrm{TiO}_{6}$ octahedra linked with three $\mathrm{PO}_{4}$ tetrahedra via oxygen sharing. Lithium is present in two different types of interstitials formed by six oxygen atoms and eight oxygen atoms respectively. These two interstitials arranged alternatively along the conduction channels provide a three dimensional network for $\mathrm{Li}$-ion transport ${ }^{5}$. The conductivity of these materials 
is further increased by heterovalent doping ${ }^{6}$. Several approaches have been developed to improve the electrochemical properties of LTP in terms of substitution of ions such as Al, $\mathrm{Zr}, \mathrm{Fe}, \mathrm{La}$ in $\mathrm{Ti}$ site or by increase of $\mathrm{Li}$ content in the unit cell ${ }^{7}$ or by generating oxygen vacancies in the lattice ${ }^{8}$. ZHAI Jing et al. studied the effect of Mn doping in $\mathrm{Li}_{3} \mathrm{~V}_{2}\left(\mathrm{PO}_{4}\right)_{3} / \mathrm{C}$ and concluded that, Mn doping effectively improved the cyclic stability and electrochemical performance of the material as cathode ${ }^{9}$. Doretta Capsoni et al. studied the effect of $\mathrm{Mn}^{2+}$ on the electrical properties of LTP in the form of $\mathrm{Li}_{1-\mathrm{x} / 2} \mathrm{Mn}_{\mathrm{x}} \mathrm{Ti}_{2-\mathrm{x} / 2}\left(\mathrm{PO}_{4}\right)_{3}$ with the supposition that $\mathrm{Mn}$ distributes evenly between $\mathrm{Li}$ and $\mathrm{Ti}$ sites ${ }^{10}$. The present paper describes the effect of $\mathrm{Mn}^{4+}$ substitution in the form of $\mathrm{Li}\left(\mathrm{Ti}_{2-\mathrm{x}} \mathrm{Mn}_{\mathrm{x}}\right)\left(\mathrm{PO}_{4}\right)_{3}$ on the electrochemical properties of LTP.

\section{Experimental}

$\mathrm{LiMn}_{\mathrm{x}} \mathrm{Ti}_{2-\mathrm{x}}\left(\mathrm{PO}_{4}\right)_{3}$ samples with $\mathrm{x}=0.0,0.1,0.3$ and 0.5 are synthesized by conventional solidstate method. Stoichiometric amounts of $\mathrm{Li}_{2} \mathrm{CO}_{3}, \mathrm{TiO}_{2}, \mathrm{NH}_{4} \mathrm{H}_{2} \mathrm{PO}_{4}$ and $\mathrm{MnO}_{2}$ for each composition were finely ground in an agate mortar in presence of methanol for $6 \mathrm{~h}$ to obtain homogeneous mixture. The powder was then calcined at $900{ }^{0} \mathrm{C}$ for $4 \mathrm{~h}$ with a heating rate of $5{ }^{\circ} \mathrm{C}$ per minute. Calcined powder which is white in colour was pressed into pellets using PVA as binder and the pellets were sintered at $1323^{0} \mathrm{~K}$ for $2 \mathrm{~h}$ on Pt foil.

Phase identification of calcined and sintered powders was performed on D8 ADVANCE Diffractometer of BRUKER AXS with $\mathrm{Cu} K \alpha 1$ radiation $\left(\lambda=1.5406 \mathrm{~A}^{0}\right)$, in the $2 \theta$ range from $10^{\circ}$ to $70^{\circ}$ in steps of $0.02^{\circ}$. Experimental densities of LTP and Mn doped LTP pellets were measured at room temperature using standard Archimedes principle. Morphology of fractured surfaces of pellets was examined by JEOL-JSM 6610LV Scanning Electron Microscope (SEM). Raman spectra are recorded on a RAMAN HORIBA JOBIN YVON-LABRAM-HR 800 Raman Spectrometer in the frequency range 50-1200 $\mathrm{cm}^{-1}$. Ionic conductivity studies are made on pellets of $12 \mathrm{~mm}$ diameter and $1.5-2.5 \mathrm{~mm}$ thickness and the measurements were carried out on a HIOKI 3532-50 LCR HITESTER LCR meter in the frequency range from $50 \mathrm{~Hz}$ to $1 \mathrm{MHz}$ and in the temperature range from $313 \mathrm{~K}$ to $573 \mathrm{~K}$. Electronic conductivities are noted using DMM by MT 4090 LCR/ESR meter in the temperature range from $303 \mathrm{~K}$ to $523 \mathrm{~K}$. In order to understand the electrochemical window of the solid state electrolyte LTP, a simple method of cyclic voltammetry has been carried out. The active material was coated on steel foil (cell) is placed in Swagelok setup containing $1 \mathrm{M} \mathrm{LiPF}_{6}$ dissolved in ethylene carbonate and dimethyl carbonate (1:1, volumetric ratio). Lithium metal was used as both counter and reference electrodes. The entire cell setup was assembled in an argon-filled glove box and tested with Biologic potentiostat/ galvanostat model VMP3 at a scan rate of $0.1 \mathrm{mV} / \mathrm{s}$ for three cycles between $0.5 \mathrm{~V}$ to $3.5 \mathrm{~V}$.

\section{Results and Discussion}

XRD patterns of LTP precursor powder heat treated at 600,800 and $900{ }^{\circ} \mathrm{C}$ for $4 \mathrm{~h}$ and at $1050{ }^{\circ} \mathrm{C}$ for $2 \mathrm{~h}$ are shown in Figure 1. From the XRD data, it is evident that the formation of $\mathrm{LiTi}_{2}\left(\mathrm{PO}_{4}\right)_{3}$ starts at $600{ }^{0} \mathrm{C}$ but the reaction does not seem to be complete at this temperature as evidenced by some extra peaks indicated therein. The intensities of these peaks decreased with increase in heat treatment temperature from 600 to $900{ }^{\circ} \mathrm{C}$ and are absent with heat treatment at $1050{ }^{\circ} \mathrm{C}$. XRD pattern of this corresponded to phase pure LTP of rhombohedral structure and all the observed peaks could be indexed as per JCPDS Card No. 35-0754. XRD patterns of $\operatorname{LiMn}_{\mathrm{x}} \mathrm{Ti}_{2-\mathrm{x}}\left(\mathrm{PO}_{4}\right)_{3}$ with $x=0.1,0.3$ and 0.5 powders heat treated at $1050{ }^{0} \mathrm{C}$ for $2 \mathrm{~h}$ depicted in Figure 2 are also in agreement with the XRD pattern for LTP $(x=0.0)$ indicating the formation of single phase compounds. 


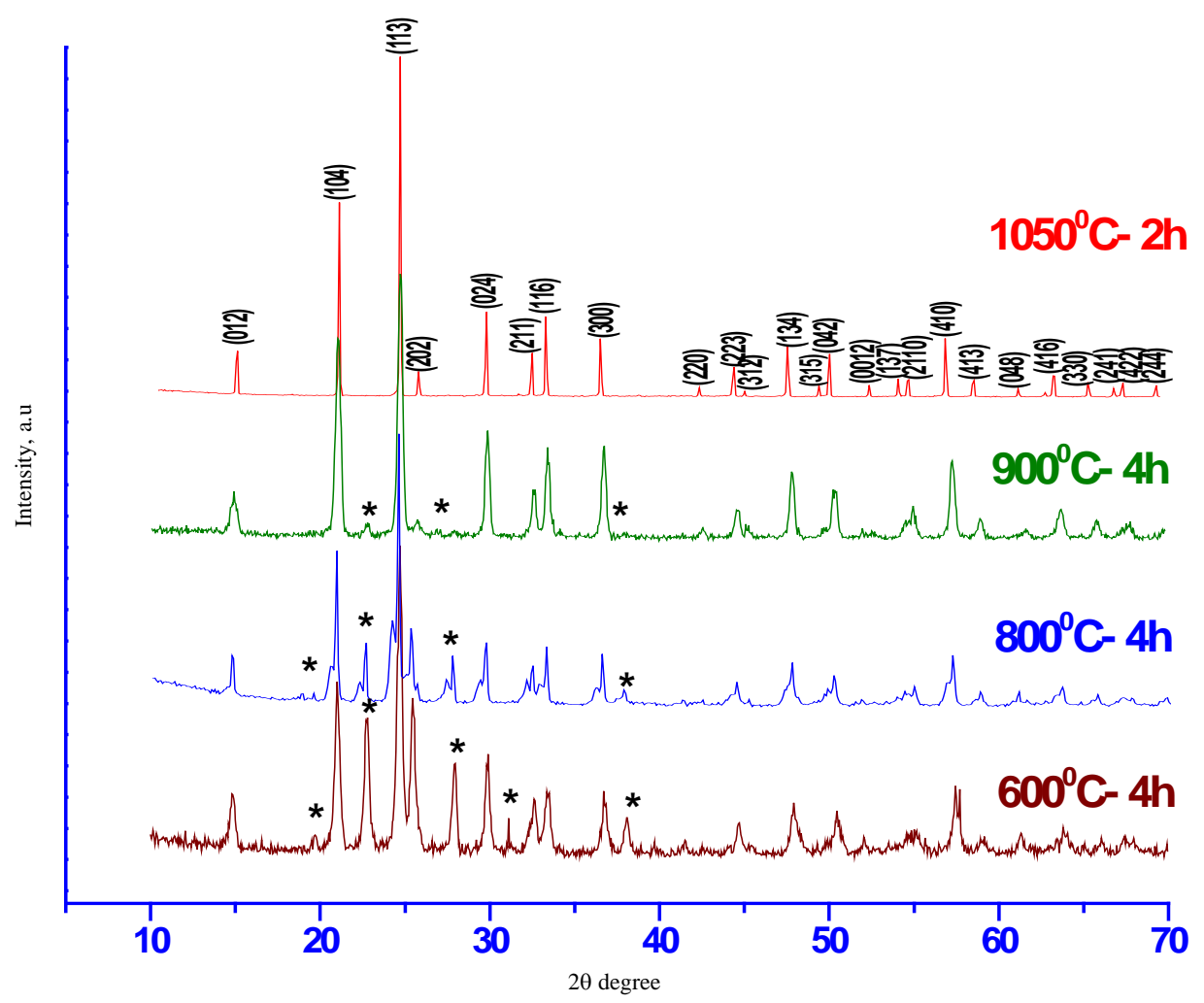

Figure 1. X-ray diffraction patterns of LTP precursor powder heat treated different temperatures

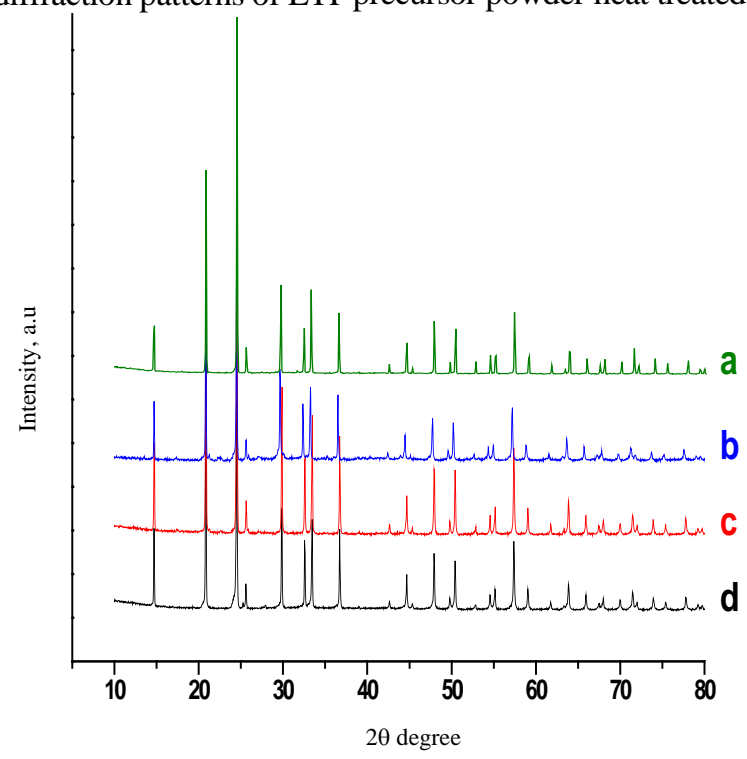

Figure 2. X-ray diffraction patterns of $\mathrm{LiMn}_{\mathrm{x}} \mathrm{Ti}_{2-\mathrm{x}}\left(\mathrm{PO}_{4}\right)_{3,}$, a $x=0.0$, (b) $x=0.1$, (c) $x=0.3$, (d) $x=0.5$ precursor powders heat treated at $1050^{\circ}$ for $2 \mathrm{~h}$ 
Cell parameters $a$ and $c$ were calculated using UNITCELL software (Unit-Cell software, 1995) are shown in Table 1. Pure LTP sample powder is white in colour while Mn doped samples are light gray colored and as Mn concentration increased the colour intensity also increased from light gray to thick gray. Lattice parameters of LTP calculated from the XRD data listed in Table 1 agree with earlier reports of crystallographic data ${ }^{11-13}$.

Table 1. Calculated lattice parameters and densities for LTP and Mn doped LTP samples

\begin{tabular}{ccccccc}
\hline Sample Name & a $\left(\mathrm{A}^{0}\right)$ & c $\left(\mathrm{A}^{0}\right)$ & $\begin{array}{c}\text { c/a } \\
\left(\mathrm{A}^{0}\right)\end{array}$ & $\begin{array}{c}\text { Experimen- } \\
\text { tal density, } \\
\text { g/cm }\end{array}$ & $\begin{array}{c}\text { Theoretical } \\
\text { density, } \\
\text { g/cm }\end{array}$ & $\begin{array}{c}\text { Relative } \\
\text { density, } \\
\%\end{array}$ \\
\hline $\mathrm{LiTi}_{2}\left(\mathrm{PO}_{4}\right)_{3}$ & 8.5135 & 20.8705 & 2.4514 & 2.76 & 2.948 & 93.6 \\
$\mathrm{Li} \mathrm{Mn}_{0.10} \mathrm{Ti}_{1.90}\left(\mathrm{PO}_{4}\right)_{3}$ & 8.5118 & 20.8771 & 2.4527 & 2.74 & 2.952 & 92.8 \\
$\mathrm{Li} \mathrm{Mn}_{0.30} \mathrm{Ti}_{1.70}\left(\mathrm{PO}_{4}\right)_{3}$ & 8.5107 & 20.8080 & 2.4449 & 2.76 & 2.975 & 92.8 \\
$\mathrm{Li} \mathrm{Mn}_{0.50} \mathrm{Ti}_{1.50}\left(\mathrm{PO}_{4}\right)_{3}$ & 8.5104 & 20.8014 & 2.4442 & 2.79 & 2.982 & 93.6 \\
\hline
\end{tabular}

Raman spectra of LTP and Mn doped LTP samples are shown in Figure 3 from which, it can be seen that four intense peaks appear at 967, 986, 1005 and $1038 \mathrm{~cm}^{-1}$ along with two other peaks at 1070 and $1092 \mathrm{~cm}^{-1}$. The peak at $1005 \mathrm{~cm}^{-1}$ is due to the symmetric stretching mode of $\mathrm{PO}_{4}^{3-}$ while the peaks at 442 and $432 \mathrm{~cm}^{-1}$ are due to the symmetric bending modes. Bands below $350 \mathrm{~cm}^{-1}$ are due to external modes and are difficult to be assigned because of mixing.

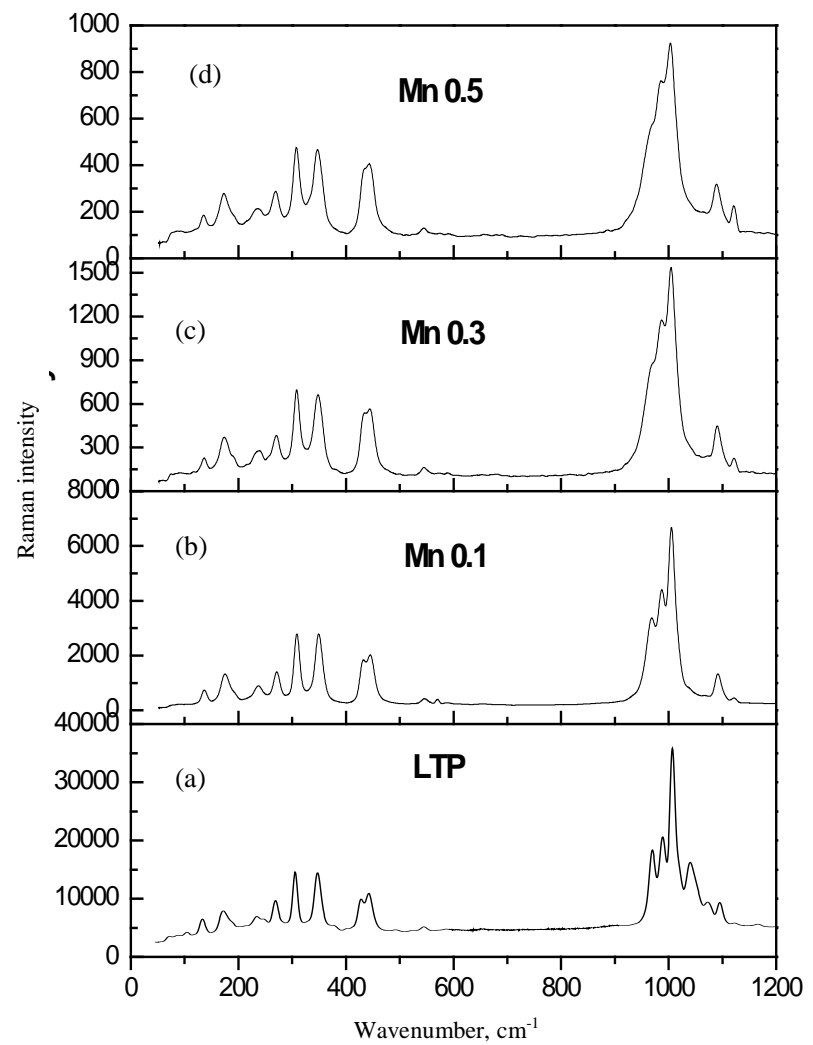

Figure 3. Raman spectra of $\operatorname{LiMn}_{\mathrm{x}} \mathrm{Ti}_{2-\mathrm{x}}\left(\mathrm{PO}_{4}\right)_{3,}$, a $x=0.0$, (b) $x=0.1$, (c) $x=0.3$, (d) $x=0.5$ sintered powders 
Raman spectra obtained for LTP agree well with report of Burba ${ }^{14}$. Mn sustitution into LTP showed several observable changes on asymmetric stretching modes. Peaks at $967 \mathrm{~cm}^{-1}$ and $986 \mathrm{~cm}^{-1}$ slowly merged into a single more intense peak with the increase in Mn content. All high intense peaks got slightly shifted to lower wavenumber side with a simultaneous increase in intensity of peaks at $1091,1121 \mathrm{~cm}^{-1}$.

Figure 4 shows SEM images of fractured surfaces of pellets of LTP and Mn doped LTP sintered at $1050{ }^{\circ} \mathrm{C}$ for $2 \mathrm{~h}$. From the SEM micrographs it can be noticed that the grain size considerably increased with increase in Mn content. Cole-Cole plots for 0.1 Mn doped LTP sample given in Figure 5 show a broadened semicircle in the high frequency region at low temperature and the size of semicircle decreased with increasing temperature. With increase in Mn doping up to 0.5, the same trend is observed.

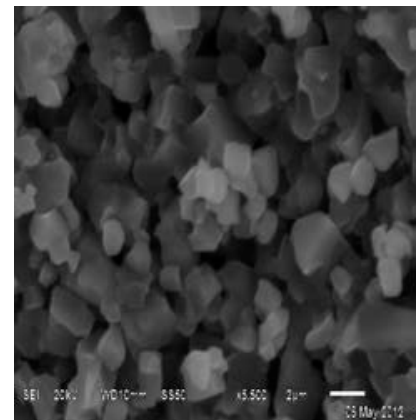

a

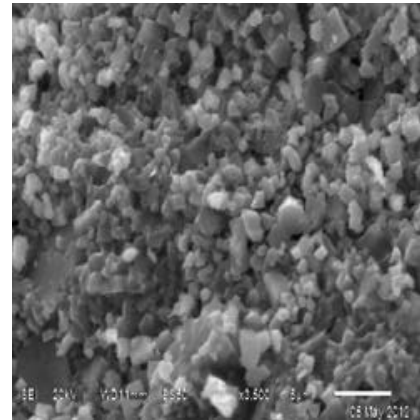

b

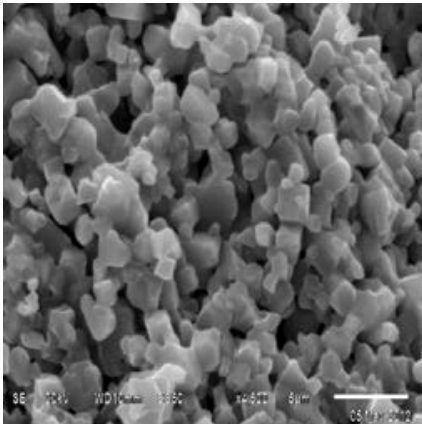

C

Figure 4. SEM micrographs of fractured surfaces of $\mathrm{LiMn}_{\mathrm{x}} \mathrm{Ti}_{2-\mathrm{x}}\left(\mathrm{PO}_{4}\right)_{3}$ pellets sintered at $1050^{\circ}$ for 2 h with (a) $x=0.0$, (b) $x=0.1$, (c) $x=0.3$, (d) $x=0.5$

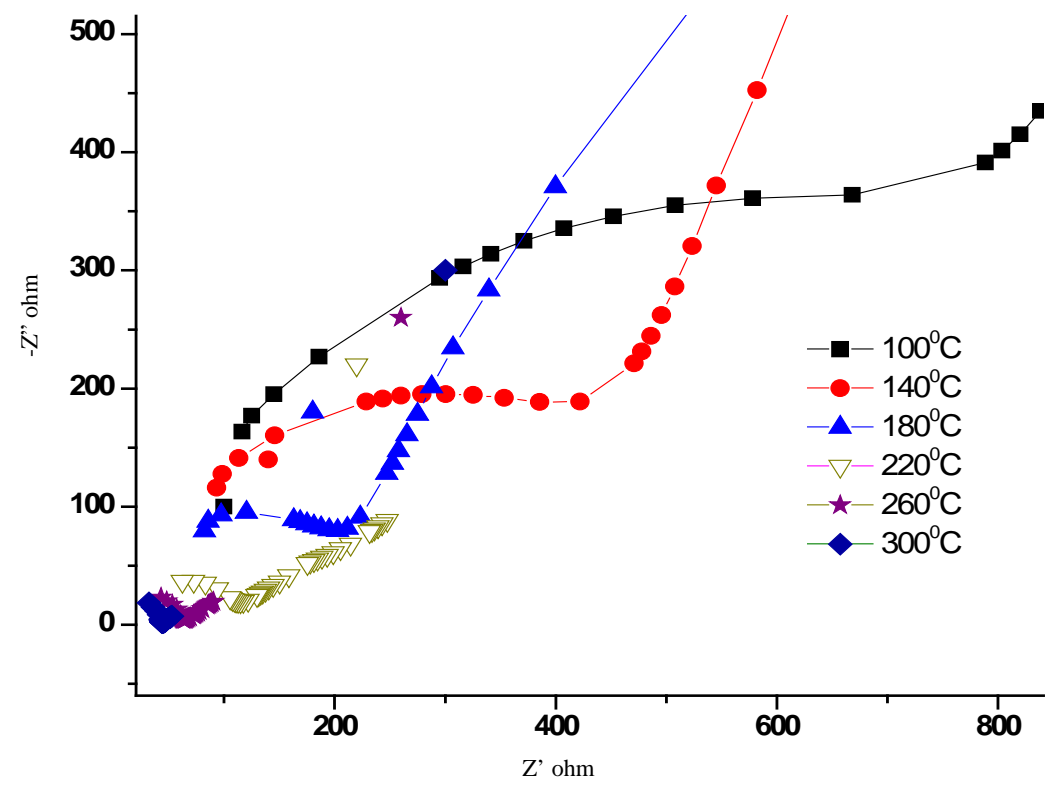

Figure 5. Cole-Cole plots of $\mathrm{Li} \mathrm{Mn} \mathrm{Mn}_{0.1} \mathrm{Ti}_{1.90}\left(\mathrm{PO}_{4}\right)_{3}$ at different temperatures (local pattern) 
Figure 6 depicts variation of a.c conductivity with temperature for LTP and Mn doped LTP samples. Ionic conductivity of $1.59 \times 10^{-4} \mathrm{~S} / \mathrm{cm}$ was observed for $\operatorname{LiMn}_{\mathrm{x}} \mathrm{Ti}_{2-\mathrm{x}}\left(\mathrm{PO}_{4}\right)_{3}$ with $x=0.1$ and decreased with increase in concentration of $\mathrm{x}>0.1$. But all the Mn doped samples showed higher conductivity compared to LTP. The a.c conductivity is calculated using the following equation;

$$
\sigma_{a . c}=\varepsilon^{\prime} \varepsilon_{o} \omega \tan \delta(S / \mathrm{cm})
$$
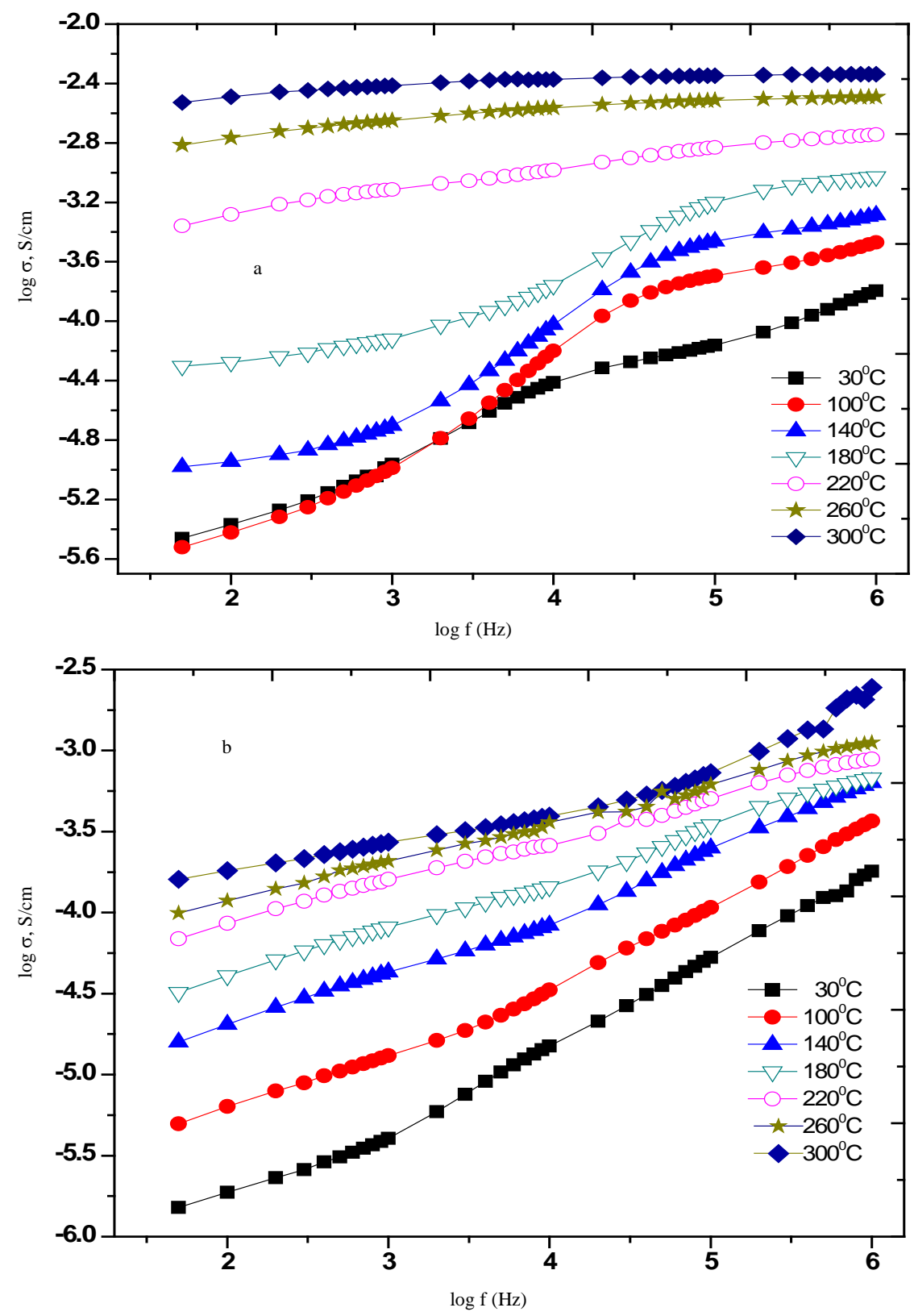


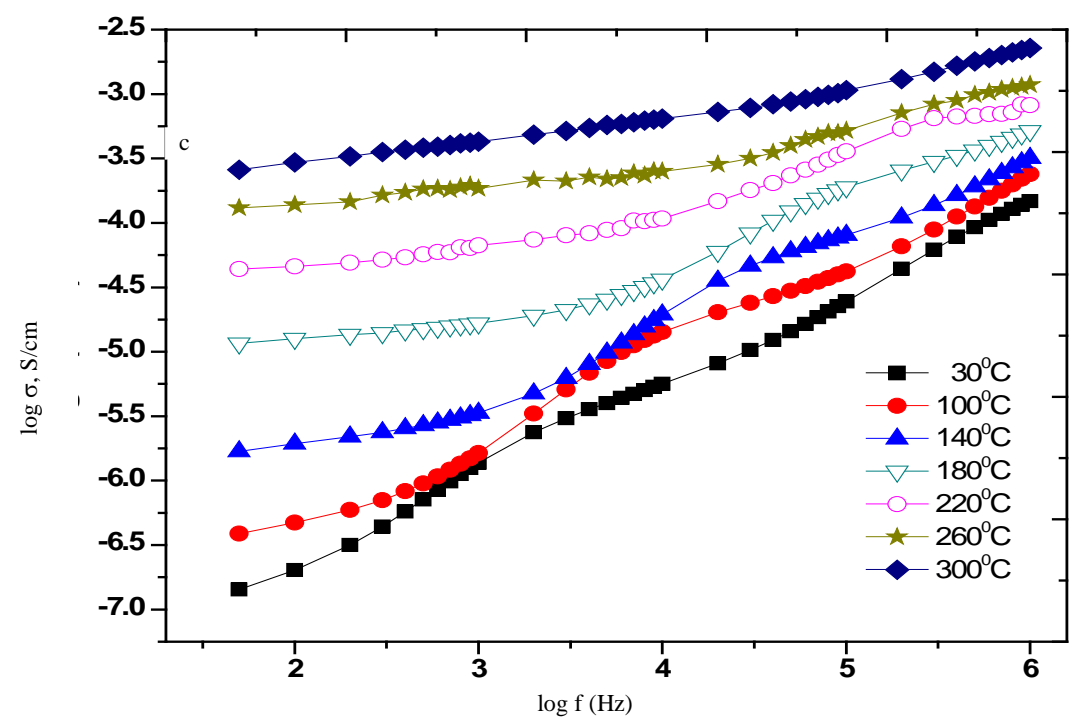

Figure 6. Variation of a.c conductivity of $\mathrm{LiMn}_{\mathrm{x}} \mathrm{Ti}_{2-\mathrm{x}}\left(\mathrm{PO}_{4}\right)_{3}$ samples with temperature (Where $\mathrm{a}=\mathrm{Mn} 0.1, \mathrm{~b}=\mathrm{Mn} 0.3$ and $\mathrm{c}=\mathrm{Mn} 0.5$ )

Where $\varepsilon^{\prime}$ is the relative dielectric constant, $\varepsilon_{0}$ is the permittivity in vacuum, $\omega$ is $2 \pi f$ and $\tan \delta$ is the dielectric loss. The measured d.c conductivity was found to be $1.23 \times 10^{-6}(\mathrm{~S} / \mathrm{cm})$. The reason for higher a.c conductivity as compared to d.c conductivity for undoped LTP was explained elsewhere ${ }^{15}$. Figure 7 shows the cyclic voltammogram of $\mathrm{Li} \mathrm{Mn}_{0.10} \mathrm{Ti}_{1.90}\left(\mathrm{PO}_{4}\right)_{3}$ sample. Initially the reduction peak is observed at $2.08 \mathrm{~V}$, but the reduction peaks are stabilized at $2.42 \mathrm{~V}$. The oxidation peaks are observed at $2.55 \mathrm{~V}$. The difference between reduction and oxidation voltages is $0.13 \mathrm{~V}$. This voltage difference is less than that observed for undoped $\operatorname{LiTi}_{2}\left(\mathrm{PO}_{4}\right)_{3}(0.24 \mathrm{~V})$. The peak intensities and electrochemical reactivity of Mn doped samples is higher than that of LTP. The data obtained suggest that electrochemical properties are improved with Mn 0.1 doping in LTP.

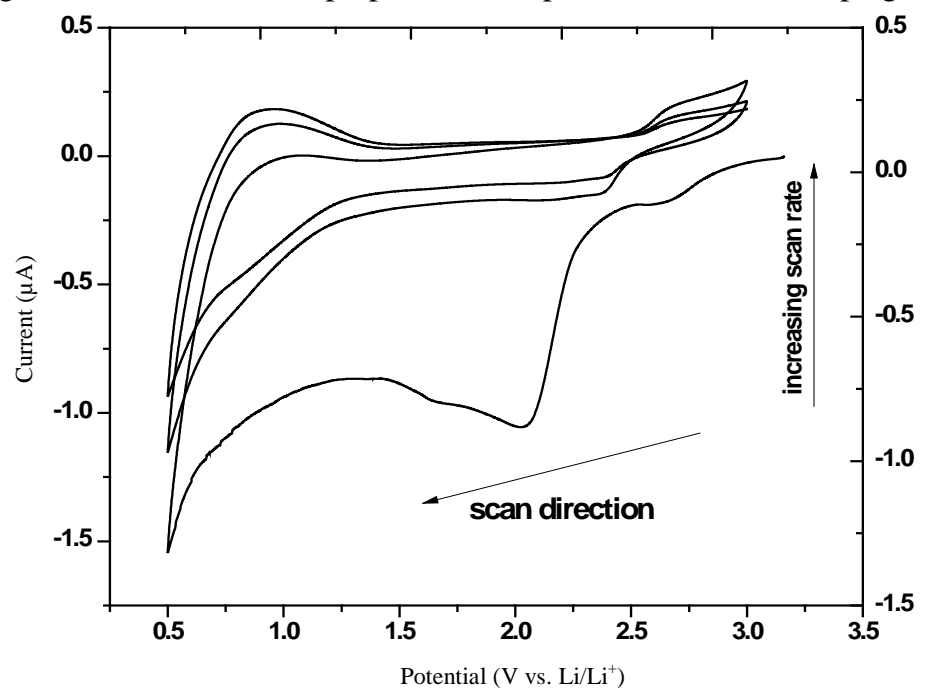

Figure 7. Cyclic voltammogram of $\mathrm{Li} \mathrm{Mn}_{0.10} \mathrm{Ti}_{1.90}\left(\mathrm{PO}_{4}\right)_{3}$ 


\section{Conclusion}

Powders of different compositions corresponding to $\mathrm{Li} \mathrm{Mn}_{\mathrm{x}} \mathrm{Ti}_{2-\mathrm{x}}\left(\mathrm{PO}_{4}\right)_{3}(x=0.0,0.1,0.3$ and 0.5 ) have been prepared by conventional solid-state method. XRD patterns of LTP heat treated at $600,800,900{ }^{\circ} \mathrm{C}$ for $4 \mathrm{~h}$ and $1050{ }^{\circ} \mathrm{C}$ for $2 \mathrm{~h}$ showed formation of phase pure LTP with rhombohedral symmetry at $1050{ }^{\circ} \mathrm{C}$. Mn-substitution in LTP led to observable shift of high intense bands to low wave number side along with an increase in intensity of peaks at 1091, $1121 \mathrm{~cm}^{-1}$ in the Raman spectra. SEM micrographs showed grain size of samples increased with increase in $\mathrm{Mn}$ content. The ionic conductivity at room temperature is $1.59 \times 10^{-4} \mathrm{~S} / \mathrm{cm}$. A.C condctivity studies indicated that low concentration of $\mathrm{Mn}$ is more effective compared to Mn concentration $0.1<x<0.5$. The measured d.c conductivity was $1.23 \times 10^{-6} \mathrm{~S} / \mathrm{cm}$. From cyclic voltammetry results it could be seen that Mn concentration of $x=0.1$ is good for enhancing the electrochemical properties of LTP.

\section{Acknowledgment}

Financial support in the form of UGC fellwoship to one of the authors (AVR) is gratefully acknowledged.

\section{References}

1. $\quad$ Hong H Y P, Mater Res Bull., 1976, 11, 173-182.

2. Kasturi Rangan K and Gopalakrishnan J, J Solid State Chem., 1994, 109(1), 116-121.

3. Aono H, Sugimoto E, Sadaoka Y, Imanaka N and Adachi G-Y, J Electrochem Soc., 1990, 137, 1023.

4. Goodenough J B, Hong H Y P and Kafalas J A, Mater Res Bull., 1976, 11, 203-220.

5. $\quad$ Wolfenstine J, Foster D, Read J and Allen J L, J Power Sources., 2008, 182, 626.

6. Pinus I Yu, Stenina I A, Rebrov A I, Zhuravlev N A and Yaroslavtsev A B, Russian J Inorg Chem., 2009, 54(8), 1177-1180.

7. Kazakevicius E, Salkus T, Dindune A, Kanepe Z, Ronis J, Kezionis A, Kazlauskiene V, Miskinis J, Selskiene A and Selskis A, Solid State Ionics, 2008, 179(1-6), 51-56.

8. Li-Juan Chen, Yu-Jun Zhao, Jia-Yan, Jia-Yan Luo and Yong-Yao Xia, Physics Letters A, 2011, 375(5), 934-938.

9. ZHAI jing, ZHAO Min-shou and WANG Dan-dan, Trans Nonferrous Met Soc China, 2011, 21(3), 523-528.

10. Doretta Capsoni, Marcella Bini, Stefania Ferrari, Piercarlo Mustarelli, Vincenzo Massarotti, Maria Cristina Mozzati and Alberto Spinella, J Phys Chem C, 2010, 114(32), 13872-13878.

11. Aatiq, Menetrier M, Croguennec L, Suard E and Delmas C, J Mater Chem., 2002, 12, 2971-2978.

12. Wang G X, Bradhurst D H, Dou S X and Liu H K, J Power Sources, 2003, 124, 231-236.

13. Joint Commission on Powder Diffraction Standards (JCPDS) Card No. 35-754, International Centre for Diffraction Data, Newtown Square, PA, USA.

14. Burba C M and Frech R, Solid State Ionics, 2006, 177, 1489.

15. Ramaraghavulu R and Buddhudu S, Ceramics International, 2011, 37, 3651. 